ISSN: $2354-1431$

http://tckh.daihoctantrao.edu.vn/

\title{
Báo cáo tóm tắt kết quả“"Nghiên cứu hệ sinh trưởng rễ, thân, lá và sinh khối năm thứ nhất của keo lai nhân giống bằng 3 phương pháp: nuôi cấy mô, dâm hom và hạt"
}

Nguyễn Văn Cuoong ${ }^{a *}$, Đoàn Thị Phuoong Lýa .

${ }^{a}$ Trường Đại học Tân Trào

*Email:nvcuong@gmail.com

\section{Thông tin bài viết}

Ngày nhận bài:

06/8/2018

Ngày duyệt đăng:

$10 / 9 / 2018$

Tù khoá:

Cây keo, keo mô, keo hom, keo hat.

\section{Tóm tắt}

Nghiên cứu hệ sinh trưởng của rễ, thân, lá và sinh khối của giống keo lai BV10 được nhân giống bằng 3 phương pháp: Nhân giống bằng nuôi cấy mô, nhân giống bằng hom và nhân giống bằng hạt cho thấy: Sinh khối giống keo mô cao hơn $86,9 \%$ so với keo hom và cao hơn $147,6 \%$ so với keo hạt. Về từng cơ quan sinh trưởng mỗi phương thức nhân giống khác nhau cũng rất khác nhau.

\section{1. Đặt vấn đề}

Tuyên Quang tỉnh miền núi phía bắc có diện tích tự nhiên 586.732 ha trong đó diện tích đất trồng rừng đến ngày $31 / 12 / 2014$ là 135.285 ha, diện tích trồng keo là 100.140 ha chiếm $74 \%$. Trong diện tích trồng keo có 20.499 ha keo lai. Trung bình mỗi năm toàn tỉnh thực hiện trồng rừng tập trung trên 13.000 ha và khai thác khoảng $300.000 \mathrm{~m}^{3}$ gỗ các loại phục vụ cho nhu cầu các nhà máy và cơ sở chế biến. Tuy nhiên, năng suất rừng trồng còn thấp $\left(70 \mathrm{~m}^{3} / \mathrm{ha} / 7-8\right.$ năm) nguyên nhân chủ yếu do công tác giống: do dùng giống keo được nhân bằng hạt, hạt giống trôi nổi không rõ nguồn gốc, 1 phần sử dụng keo nhân giống bằng hom tuy nhiên những cây giống sử dụng lấy hom, 1 số cây lấy hom để lâu (3-4 năm) giống đã già về tuổi bố mẹ, diện tích rừng được trồng bằng giống nhân bằng phương pháp nuôi cấy mô còn hạn chế (năm 2010 đến 2015 toàn tỉnh mới trồng được 179,1 ha)(Số liệu: sở NN\&PTNT (2015) Báocáo tổng kết năm 2015)

Ghi chú: Trong báo cáo này: Phuơng pháp nhân giống keo lai bằng hạt gọi tắt keo hạt; phuơng pháp nhân giống keo lai bằng hom gọi tắt keo hom; phưong pháp nhân giống keo lai bằng nuôi cấy mô goi tắt keo mô.

Qua kết quả nghiên cứu của nhiều đơn vị trồng trong cả nước như: Công ty trách nhiệm hữu hạn lâm nghiệp Tiền Phong - Thừa Thiên huế năm 2004 công ty trồng 5 ha keo lai nhân giống bằng phương pháp nuôi cấy mô năm 2015 thu được $150 \mathrm{~m}^{3} / \mathrm{ha} / 10$ năm; năm 2012 - 2014 trồng 750 ha trồng rừng bằng giống keo lai nhân bằng phương pháp nuôi cấy mô theo dõi sau hơn 2 năm trồng đường kính gốc và chiều cao tăng hơn cây hom 1,5 lần, Công ty TNHH MTV lâm nghiệp Bến Hải, tỉnh Quảng Trị trồng $100 \%$ diện tích bằng keo mô năng suất ước đạt $130 \mathrm{~m}^{3} / \mathrm{ha} / 7$ năm.

Việc đưa giống keo lai nhân giống bằng phương pháp nuôi cấy mô vào trồng rừng trong tỉnh là 1 yêu cầu vừa cần thiết và vừa cấp bách nó góp phần nâng cao năng suất rừng trồng, phủ xanh đất trống góp phần xóa đói, giảm ngheo, nâng cao thu nhập người trồng rừng.

Đối với Tuyên Quang để chuyển đổi được nhận thức người trồng rừng từ trồng rừng bằng keo hạt, keo hom không được kiểm soát sang trồng rừng bằng keo mô đòi hỏi phải phải có mô hình và các số liệu khoa học minh chứng. Vì lý do trên việc nghiên cứu hệ sinh trưởng của rễ, thân lá và khả năng sinh khối của keo lai được nhân giống bằng 3 phương pháp: hạt, hom, mô là cần thiết.

\section{Vật liệu và phương pháp nghiên cứu}

\subsection{Vật liêu nghiên cứu}


Giống keo lai BV10, cây giống 5 tháng tuổi, được nhân giống bằng 3 phương pháp: Nhân giống bằng hạt; nhân giống bằng hom; nhân giống bằng nuôi cấy mô.

\subsection{Phuơng pháp nghiên cúu}

- Thử nghiệm ngoài đồng ruộng, mỗi giống trồng 48 cây $x 3$ giống $=144$ cây, mật độ: hàng cách hàng $3 \mathrm{~m}$, cây cách cây $3 \mathrm{~m}$, trồng đất ven đồi, đào hố trồng bằng máy $80 \mathrm{~cm} \mathrm{x} 80 \mathrm{~cm}$ sâu $50 \mathrm{~cm}$, bón lót trước khi trồng $0,05 \mathrm{~kg}$ NPK $5-10-3$; bón thúc 2 lần NPK12-5-10 vào tháng 6 và tháng 10 mỗi lần $0,005 \mathrm{~kg} / \mathrm{gốc}$, làm cỏ 2 lần vào tháng 6 và tháng 10 năm 2016.

- Các chỉ tiêu theo dõi: rễ; thân; lá; sinh khối, chiều cao cây

+ Rễ:

Cách lấy rễ: Đào lấy toàn bộ rễ bằng cách đào sâu xung quanh rễ sau đó bơm nước ngâm rễ cho đất tơi ra, và dùng tay với dụng cụ nhỏ tách dần đất ra khỏi rễ.

Cách xác định rễ theo dõi: đếm những rễ to đã hình thành thân rễ, cổ rễ, chóp rễ.

Theo dõi khối lượng rễ; chiều dài rễ; cổ rễ to nhất

+ Thân theo dõi khối lượng thân; chiều cao thân; đường kính gốc

Cách đo: Tính từ điểm cổ rễ trên cùng đến vút chóp ngọn cao nhất.

+ Lá theo dõi khối lượng lá (tách lá khỏi thân, cành sau đó cân toàn bộ)

+ Chiều cao cây: đo toàn bộ từ rễ đến chóp ngọn cao nhất

+ Sinh khối: Cân trọng lượng toàn bộ cây.

- Theo dõi số liệu 2 lần vào các thời gian: Trước khi trồng; sau trồng 10 tháng (tháng 12 năm 2016); mỗi lần theo dõi 3 cây/1 giống (Cây đã cố định trong thử nghiệm) đào lấy toàn bộ rễ , thân, lá để cân, đo lấy số liệu trung bình.

\section{Kết quả và thảo luận}

Thời gian thực hiện: trồng ngày 27/2/2016, theo dõi ngày 17/12/2016, giống keo trồng BV10, tuổi keo khi trồng: 6 tháng tuổi, kết quả cụ thể

\subsection{Kết quả theo dõi hệ rễ}

Kết quả theo dõi hệ rễ keo được thể hiện tại bảng 1
Bảng 1. Kết quả theo dõi hệ rễ keo

\begin{tabular}{|c|c|c|c|c|c|c|c|c|c|}
\hline \multirow[b]{2}{*}{ Công thise } & \multirow[b]{2}{*}{$\begin{array}{c}\text { Don } \\
\text { vi }\end{array}$} & \multicolumn{2}{|c|}{ Keo hom } & \multicolumn{2}{|c|}{ Keo bạt } & \multicolumn{4}{|c|}{ Keo mô } \\
\hline & & $\begin{array}{l}\text { Ngày } \\
\text { trầng }\end{array}$ & $\begin{array}{l}\text { Ngày } \\
\text { theo döi }\end{array}$ & $\begin{array}{l}\text { Ngày } \\
\text { trồng }\end{array}$ & $\begin{array}{l}\text { Ngày } \\
\text { theo } \\
\text { dôi }\end{array}$ & $\begin{array}{l}\text { Ngày } \\
\text { trồng }\end{array}$ & $\begin{array}{c}\text { Ngày } \\
\text { theo dơi }\end{array}$ & $\begin{array}{l}\text { Tý lêt } \\
\text { (\%) } \\
\text { so cay } \\
\text { hom }\end{array}$ & $\begin{array}{c}\text { Tý lẹ \% } \\
\text { so cây } \\
\text { hạt }\end{array}$ \\
\hline $\begin{array}{c}\text { Khối } \\
\text { lượng rễ }\end{array}$ & $\mathrm{B}$ & 0,88 & 1030,0 & 0,98 & 970 & 0,91 & 1610 & 156,3 & 165,9 \\
\hline $\begin{array}{c}\text { Chièu dâi } \\
\text { rế }\end{array}$ & $\mathrm{cm}$ & 16,0 & 95,6 & 14,83 & 81,67 & 15,8 & 132,6 & 138,7 & 162,3 \\
\hline $\begin{array}{c}\text { Cổ rễ to } \\
\text { nhắt }\end{array}$ & $\mathrm{cm}$ & 0,18 & 2,27 & 0,32 & 2,42 & 0,43 & 3,8 & 167,4 & 157,0 \\
\hline $\begin{array}{c}\text { Số lương } \\
\text { rễ câi }\end{array}$ & \begin{tabular}{|l|} 
ré \\
eái
\end{tabular} & 3 & 12,3 & 4 & 12,97 & 4 & 18,3 & 137,5 & 141,0 \\
\hline
\end{tabular}

Nhận xét:

- Khối lượng rễ, chiều dài rễ khi trồng (keo 5 tháng tuổi) có khối lượng tương đối bằng nhau, sự chênh lệch không lớn. Tuy nhiên, cổ rễ và số lượng rễ cái của keo hạt và keo mô có kích thước và số lượng lớn hơn keo hom.

- Ngày theo dõi (sau trồng 10 tháng), sinh trưởng hệ rễ đã có nhiều sai khác. Keo mô khối lượng rễ tăng $56,3 \%$ so keo hom và tăng $65,9 \%$ so với keo hạt, chiều dài rễ keo mô tăng $38,7 \%$ so keo hom và tăng $62,3 \%$ so với keo hạt.

- Các chỉ tiêu cổ rễ to nhất và số lượng rễ cái keo hạt và keo mô đều cao hơn keo hom.

- Số lượng rễ cái keo mô tăng 37,5\% so keo hom và $41 \%$ so với keo hạt.

\subsection{Kết quả theo dõi hệ thân}

Kết quả nghiên cứu hệ thân được thể hiện tại bảng 2

\section{Bảng 2. Kết quả so sánh của hệ thân keo}

(Theo dõi ngày 17/12/2016)

\begin{tabular}{|c|c|c|c|c|c|c|c|c|c|}
\hline \multirow[b]{2}{*}{ Cong thise } & \multirow[b]{2}{*}{ DVT } & \multicolumn{2}{|c|}{ Keo hom } & \multicolumn{2}{|c|}{ keo hạt } & \multicolumn{4}{|c|}{ Keo mố } \\
\hline & & $\begin{array}{l}\text { Ngly } \\
\text { trồng }\end{array}$ & $\begin{array}{l}\text { Nghy } \\
\text { theo } \\
\text { dôi }\end{array}$ & $\begin{array}{l}\text { Ngaly } \\
\text { trầng }\end{array}$ & $\begin{array}{c}\text { Ngdy } \\
\text { theo } \\
\text { döi }\end{array}$ & $\begin{array}{l}\text { Ngìy } \\
\text { trờng }\end{array}$ & $\begin{array}{l}\text { Ngly } \\
\text { theo } \\
\text { doi }\end{array}$ & $\begin{array}{l}\text { Ty le } \\
(\%) \\
\text { so caly } \\
\text { hom }\end{array}$ & $\begin{array}{c}\text { Ty lef } \\
(\%) \\
\text { so caly } \\
\text { Hạt }\end{array}$ \\
\hline $\begin{array}{l}\text { Khở lurợng } \\
\text { thân cành }\end{array}$ & $\mathrm{g}$ & 2,73 & 2066,7 & 1,50 & 1483,3 & 1,45 & 4033,3 & 195,1 & 271,9 \\
\hline $\begin{array}{l}\text { Dưưng kinh } \\
\text { gấc }\end{array}$ & $\mathrm{cm}$ & 0,35 & 3,93 & 0,30 & 3,83 & 0,37 & 5,87 & 149,3 & 153,2 \\
\hline $\begin{array}{l}\text { Thîn /thân } \\
\text { chính }\end{array}$ & Thẩn & 1 & 1,2 & 1 & 1,0 & 1 & 1,1 & 91,6 & 110 \\
\hline
\end{tabular}

Nhận xét:

- Ngày trồng: Khối lượng thân cành keo hom cao hơn keo hạt và keo mô song sự sai khác là không lớn. Đường kính gốc của keo hom, keo hạt và keo mô tương đương nhau $(0,35 ; 0,3$ và $0,37 \mathrm{~cm})$.

Thân chính khi trồng đều bằng nhau là 1 thân.

- Ngày theo dõi (sau trồng 10 tháng).

Sinh trưởng hệ thân đã có sự sai khác rõ rệt. Khối lượng thân, cành: keo mô tăng $95,1 \%$ so keo hom và tăng $171,9 \%$ so keo hạt. 
Đường kính gốc: keo mô tăng 49,3\% so keo hom và tăng 53,3\% so keo hạt.

Thân/thân chính: keo hom khả năng hình thành thân phụ (1,2 thân/thân chính) nhiều hơn so keo hạt (1/1 thân) và keo mô (1,1/1 thân). Như vậy, khả năng phân thân của keo hom cao hơn keo mô và keo mô cao hơn keo hạt, khả năng phân thân keo hạt gần như không có.

\subsection{Kết quả theo dõi hệ lá}

Kết quả nghiên cứu hệ lá được thể hiện tại bảng 3

Bảng 3. Kết quả so sánh của hệ lá keo

\begin{tabular}{|c|c|c|c|c|c|c|c|c|c|}
\hline \multirow[b]{2}{*}{$\begin{array}{l}\text { Công } \\
\text { thức }\end{array}$} & \multirow[b]{2}{*}{$\begin{array}{l}\text { Đon } \\
\text { vi }\end{array}$} & \multicolumn{2}{|c|}{ Keo hom } & \multicolumn{3}{|c|}{ Keo hạt } & \multicolumn{3}{|c|}{ Keo mô } \\
\hline & & $\begin{array}{l}\text { Ngày } \\
\text { trồng }\end{array}$ & $\begin{array}{c}\text { Ngày } \\
\text { theo } \\
\text { dōi }\end{array}$ & $\begin{array}{l}\text { Ngày } \\
\text { trờng }\end{array}$ & $\begin{array}{l}\text { Ngày } \\
\text { theo } \\
\text { dõi }\end{array}$ & $\begin{array}{l}\text { Ngày } \\
\text { trồng }\end{array}$ & $\begin{array}{l}\text { Ngày } \\
\text { theo } \\
\text { dói }\end{array}$ & $\begin{array}{l}\text { Tỳ lê } \\
(\%) \\
\text { so cây } \\
\text { hom }\end{array}$ & $\begin{array}{c}\text { Ty le } \\
\text { (\%) } \\
\text { so caly } \\
\text { hat }\end{array}$ \\
\hline $\begin{array}{c}\text { Khối } \\
\text { lượng lá }\end{array}$ & 8 & 3,78 & 1826,5 & 2,4 & 1266,7 & 4,06 & 3566,7 & 195,3 & 281,5 \\
\hline
\end{tabular}

Nhận xét:

- Ngày trồng: Số lượng lá keo hom 3,78 g trong khi keo hạt có khối lượng lá bằng $1,4 \mathrm{~g}$ và khối lượng lá keo mô 4,06 g. Có thể nhận thấy ngay từ ngày trồng số lượng lá keo mô là cao nhất, cao hơn keo hom $7,4 \%$ và cao hơn keo hạt $69,1 \%$.

- Ngày theo dõi: Số lượng lá keo mô cao hơn keo hom 95,3\% và cao hơn keo hạt 181,5\%.

\subsection{Kết quả theo dõi chiều cao cây}

Kết quả nghiên cứu chiều cao cây được thể hiện tại bảng 4

\section{Bảng 4. So sánh kết quả chiều cao cây keo}

\begin{tabular}{|c|c|c|c|c|c|c|c|c|c|}
\multirow{2}{*}{$\begin{array}{c}\text { Công } \\
\text { thức }\end{array}$} & \multirow{2}{*}{$\begin{array}{c}\text { Đơn } \\
\text { vị }\end{array}$} & \multicolumn{2}{|c|}{ Keo hom } & \multicolumn{2}{|c|}{ Keo hạt } & \multicolumn{4}{|c|}{ Keo mòy } \\
trồng & $\begin{array}{c}\text { Ngày } \\
\text { theo } \\
\text { dõi }\end{array}$ & $\begin{array}{c}\text { Ngày } \\
\text { trồng }\end{array}$ & $\begin{array}{c}\text { Ngày } \\
\text { theo } \\
\text { dõi }\end{array}$ & $\begin{array}{c}\text { Ngày } \\
\text { trồng }\end{array}$ & $\begin{array}{c}\text { Ngày } \\
\text { theo } \\
\text { dõi }\end{array}$ & $\begin{array}{c}\text { Tỷ lệ } \\
(\%) \\
\text { so cây } \\
\text { hom }\end{array}$ & $\begin{array}{c}\text { Tỷ lệ } \\
(\%) \\
\text { so cây } \\
\text { Hạt }\end{array}$ \\
\hline $\begin{array}{c}\text { Chiều } \\
\text { cao cây }\end{array}$ & $\mathrm{m}$ & 0,33 & 2,75 & 0,3 & 1,44 & 0,27 & 3,92 & 142,5 & 272,2 \\
\hline
\end{tabular}

Nhận xét:

- Chiều cao cây khi trồng keo hom và keo hạt đều tương đương nhau $(0,33 \mathrm{~m}, 0,3 \mathrm{~m})$, riêng keo mô có thấp hơn $(0,27 \mathrm{~m})$.

- Tại thời điểm theo dõi (sau trồng 10 tháng), chiều cao đã có sự sai khác rõ rệt. Chiều cao cây keo mô cao hơn keo hom 42,5\% và cao hơn keo hạt 172,2\%.

\subsection{Kết quả theo dõi sinh khối}

Sinh khối của cây là tổng khối lượng sinh khối của rễ, thân, lá.

Kết quả nghiên cứu sinh khối cây được thể hiện tại bảng 5
Bảng 5. Kết quả theo dõi sinh khối của cây keo

\begin{tabular}{|c|c|c|c|c|c|c|c|c|c|}
\hline \multirow[b]{2}{*}{$\begin{array}{l}\text { Công } \\
\text { thức }\end{array}$} & \multirow[b]{2}{*}{$\begin{array}{c}\text { Don } \\
\text { vị }\end{array}$} & \multicolumn{2}{|c|}{ Keo hom } & \multicolumn{2}{|c|}{ Keo hạt } & \multicolumn{4}{|c|}{ Keo mổ } \\
\hline & & $\begin{array}{l}\text { Ngaly } \\
\text { trừng }\end{array}$ & $\begin{array}{c}\text { Ngìy } \\
\text { theo } \\
\text { dōi }\end{array}$ & $\begin{array}{l}\text { Nggì } \\
\text { trừng }\end{array}$ & $\begin{array}{c}\text { Nggiy theo } \\
\text { doi }\end{array}$ & $\begin{array}{l}\text { Ngìy } \\
\text { trừng }\end{array}$ & $\begin{array}{l}\text { Nggiy } \\
\text { theo } \\
\text { dōi }\end{array}$ & $\begin{array}{l}(\%) \\
\text { so cây } \\
\text { hom }\end{array}$ & $\begin{array}{l}\text { (\%) } \\
\text { so cây } \\
\text { Hạt }\end{array}$ \\
\hline $\begin{array}{l}\text { Tổng } \\
\text { khồt } \\
\text { hrợng }\end{array}$ & $\mathrm{kg}$ & 0,0074 & 4926,2 & 0,0062 & 3720,0 & 0,0065 & 9210,0 & 186,9 & 247,6 \\
\hline
\end{tabular}

Nhận xét:

Khối lượng cây là chỉ tiêu tổng hợp đánh giá sinh trưởng của cây. Là chỉ tiêu quyết định trong sản xuất. Kết quả theo dõi khối lượng cây tại bảng 5 cho thấy:

- Ngày trồng khối lượng keo hạt, keo hom và keo mô tương đương nhau $(0,0074 \mathrm{~g}, 0,0062 \mathrm{~g}, 0,0065 \mathrm{~g})$.

- Ngày theo dõi (sau trồng 10 tháng) khối lượng cây đã có sự sai khác rõ rệt. Keo mô cao hơn keo hom $86,9 \%$ và cao hơn keo hạt $147,6 \%$.

\subsection{Kết quả theo dõi về sâu, bệnh và khả năng} chống chịu

Sau 10 tháng theo dõi không xuất hiện sâu và bệnh trên 3 loại keo.

Năm 2016 không xuất hiện các trận bão lớn, mặt khác keo mới trồng 1 năm nên chưa kết luận được khả năng chống chịu của các điều kiện ngoại cảnh bất lợi.

\section{Nhận xét}

Số liệu trong thử nghiệm trên mới được theo dõi trong 10 tháng. Tuy nhiên, phần nào đã phản ánh được tốc độ sinh trưởng của hệ rễ, thân, lá, sinh khối và chiều cao của cây keo được nhân giống bằng 3 phương pháp: Nhân giống bằng hạt, nhân giống bằng hom và nhân giống bằng nuôi cấy mô.

Qua kết quả trên có thể thấy rõ cây keo mô cho tốc độ sinh trưởng cả rễ, thân, lá, chiều cao cây là nhanh nhất sau đó đến keo hom và tốc độ tăng trưởng chậm nhất là keo hạt.

Tốc độ sinh trưởng mỗi cơ quan khác nhau là khác nhau; lá có tốc độ sinh trưởng nhanh nhất sau đến thân và đến rễ đây là cơ sở khoa học trong việc xây dựng quy trình trồng, chăm sóc và thu hoạch keo sao cho phù hợp sinh trưởng và phát triển của cây.

Kết quả của đề tài đã bổ sung cơ sở thực tiễn trong sản xuất, củng cố lòng tin cho các cơ sở kinh doanh, hộ gia đình và cá nhân trồng keo bằng giống keo sản xuất bằng phương pháp nuôi cấy mô cho năng xuất cao và rút ngắn được thời gian sản xuất, nâng cao hiệu quả trong sản xuất trồng rừng. 
Kết quả đề tài là cơ sở khoa học được tổng kết cả về lý luận và thực tiễn để bổ sung và hoàn chỉnh về công nghệ sản xuất giống nói chung và cây keo nói riêng.

\section{Kết luận và đề nghị}

\subsection{Kết luận}

Sau 1 năm theo dõi khả năng sinh khối của keo được tạo giống bằng 3 phương pháp cho thấy:

- Keo mô khả năng sinh khối cao hơn keo hom $86,9 \%$ và cao hơn keo hạt $147,6 \%$.

- Các hệ sinh khối của cây mô đều tăng cao hơn keo hom và keo hạt song khả năng tăng trưởng các hệ khác nhau thì khác nhau.

+ Khối lượng lá của keo mô tăng trưởng nhanh nhất, cao hơn keo hom 95,3\% và cao hơn keo hạt $181,5 \%$.

+ Khối lượng thân cành của keo mô có tốc độ tăng trưởng nhanh sau lá, khối lượng thân cành keo mô tăng trưởng cao hơn keo hom $95,1 \%$ và cao hơn keo hạt $171,9 \%$.

+ Khối lượng rễ của keo mô tăng 56,3\% so keo hom và tăng $65,9 \%$ so keo hạt.

- Khả năng phân thân của keo hom 1,2 thân/thân chính trong khi keo mô 1,1 thân/thân chính và keo hạt 1 thân/1 thân chính.

- Chiều cao keo mô tăng cao hơn cây hom 42,5\% và cao hơn keo hạt $172 \%$.
- Trong thời gian theo dõi mới 10 tháng chưa xuất hiện sâu bệnh và các điều kiện bất lợi nên chưa kết luận được khả năng chống chịu.

\section{2. Đề nghị}

Đề tài thực hiện trong thời gian 1 năm do đó kết luận về khả năng sinh khối và khả năng chống chịu mới ở bước đầu do đó để có số liệu đầy đủ cần tiếp tục theo dõi những năm tiếp theo.

Trong phạm vi nhà trường với nguồn kinh phí đề tài ở cấp cơ sở còn hạn hẹp, mặt khác đề tài thực hiện trong phạm vi hẹp $\left(1400 \mathrm{~m}^{2}\right)$ vì vậy để có số liệu chính xác cần thực hiện trên diện tích lớn từ 2-3 ha.

\section{TÀI LIỆU THAM KHẢO}

1. Viện khoa học Lâm nghiệp Việt Nam (2015), Quy trình nhân giống keo lai bằng phuoong pháp nuôi cấy mô;

2.Sở NN \& PTNT tỉnh Tuyên Quang (2015), Báo cáo tổng kết năm 2015;

3.GS.TS. Hoàng Minh Tấn (2006), Giáo trình sinh lý thưc vật, Nxb NN, Hà Nội;

4. Đoàn Thị Mai (2012), Báo cáo kết quả đề tài cấp bộ về nhân giống keo lại bằng phuoong pháp nuôi cấy mô;

5. Lâm trường Tiền phong - Thừa Thiên Huế (2015), Báo cáo kết quả trồng thử nghiệm keo lai nhân giống bằng phuơng pháp nuôi cấy mô với keo hom.

\section{Summarising Report of the study "Researching growth system of root, trunk, leaves and biomass of the $1^{\text {st }}$ year hybrid black wood in three methods: transplant of tissue, cutting and seeds"}

Nguyen Van Cuong, Doan Thi Phuong Ly

\section{Article info}

Recieved:

06/8/2018

Accepted:

$10 / 9 / 2018$

Keywords:

Black wood, seed black wood, tissue black wood, cutting black wood.

\begin{abstract}
Researching growth system of root, trunk, leaves and biomass of 1st year hybrid black wood BV10 which is multiplied by 3 methods: transplant of tissue; cutting and seeds, and it shows: biomass of tissue black wood is $86,9 \%$ higher than cutting black wood and is $147,6 \%$ and higher than the seed one. In each growth system and each multiplied method,there are also differences among them.
\end{abstract}

